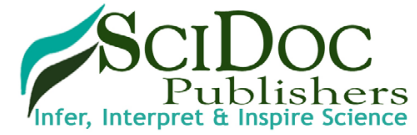

\section{Pseudoepitheliomatous Hyperplasia in the Setting of CD30+ Lymphoproliferative Disease: A Histologic Mimic of Squamous Cell Carcinoma that Exhibits Indolent Clinical Behavior}

Case Study

Helm $\mathrm{MM}^{1 *}$, Grassi $\mathrm{M}^{2}$, Bax MJ

${ }^{1}$ Rensselaer Polytechnic Institute in Troy, NY, USA.

${ }^{2}$ Jacobs School of Medicine, Buffalo, NY, USA.

${ }^{3}$ Roswell Park Cancer Institute Department of Dermatology, Buffalo, NY, USA.

\section{Introduction}

There are reports of keratoacanthomas as well as pseudocarcinomatous hyperplasia (PEH) mimicking poorly differentiated squamous cell carcinoma arising in the setting of CD30+ lymphoproliferative disease $[1,2]$. Although the prominent $\mathrm{PEH}$ noted in some individuals closely mimics squamous cell carcinoma on biopsy, the indolent clinical behavior indicates that this phenomenon is best considered a reactive change $[3,4]$.

\section{Case}

A woman in her 50s presented for evaluation of a nodule on the upper lip (Figure 1) and erythematous papules on the neck and trunk. She had a greater than 20 year history of mycosis fungoides which had been well controlled with topical nitrogen mustard and later with phototherapy. Her new lesions had developed over several weeks and were asymptomatic. Biopsy revealed irregular acanthosis of the epidermis and an infiltrate of atypical lymphoid cells in the dermis (Figure 2). Gene re-arrangement studies confirmed the presence of monoclonal lymphocytes. CD30 and CD3 stains confirmed that the neoplastic cells were $\mathrm{T}$ lymphocytes (Figure 3). Although squamous cell carcinoma arising in association with lymphomatoid papulosis was initially favored, careful review of her histologic and clinical findings best supported a diagnosis of PEH arising in the setting of CD30+ lymphoproliferative disease. Additional biopsies confirmed large cell transformation of her mycosis fungoides with large number of CD30+ atypical lymphocytes in the dermal infiltrate. Simple excision of multiple nodules led to resolution of the excised lesions. She was placed on brentuximab vedotin and has had a stable course.

\section{Discussion}

CD30+ lymphoproliferative disease encompasses a broad clinical spectrum that includes clusters of regressing papules and nodules that come and go over many years to rapidly fatal lymphoma. Differences in underlying genetic abnormalities of the tumor and host response seem to play a critical role in determining the ultimate phenotypic expression of underlying disease. Typical lymphomatoid papulosis, solitary ulcerated tumors, and tumors arising in association with mycosis fungoides can all exhibit similar findings on biopsy. Distinct subtypes of lymphomatoid papulosis include the common presentation characterized by a mixed infiltrate with transformed lymphocytes in the dermis, a mycosisfungoides-like epidermotropic pattern, sheets of transformed cells mimicking aggressive lymphoma, a cytotoxic phenotype, an angioinvasive pattern, and a biphasic pattern associated with a 6p25.3 chromosomal rearrangement [5].

CD30+ lymphoproliferative disease can also arise in the setting of longstanding mycosis fungoides as in our patient [6]. The large cell transformation of mycosis fungoides is associated with dense infiltrates in the dermis, unlike the more limited infiltrate of epidermal CD30+ lymphocytes encountered in some forms of mycosis fungoides [7].

Marked pseudoepitheliomatous hyperplasia is a relatively uncommon but increasingly recognized association with CD30+ lymphoproliferative disease and other types of lymphoma $[8,9]$. Histologic evaluation reveals projections of epithelium with jagged bases extending into the dermis [10]. Keratinocyte atypia is usually mild and confined to the basal layer of the epithelium. Keratin pearls may be noted but atypical mitoses are generally

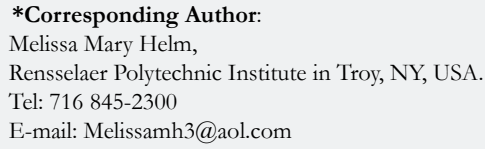

Citation: Helm MM, Grassi M, Bax MJ. Pseudoepitheliomatous Hyperplasia in the Setting of CD30+ Lymphoproliferative Disease: A Histologic Mimic of Squamous Cell Carcinoma that Exhibits Indolent Clinical Behavior. Int J Clin Dermatol Res. 2017;5(7):151-153. doi: http://dx.doi.org/10.19070/2332-2977-1700034

Copyright: Helm $\mathbf{M M}^{\circ}$ 2017. This is an open-access article distributed under the terms of the Creative Commons Attribution License, which permits unrestricted use, distribution and reproduction in any medium, provided the original author and source are credited. 
Figure 1. A crusted and dome shaped lesion developed rapidly on the upper lip near the philtrum.

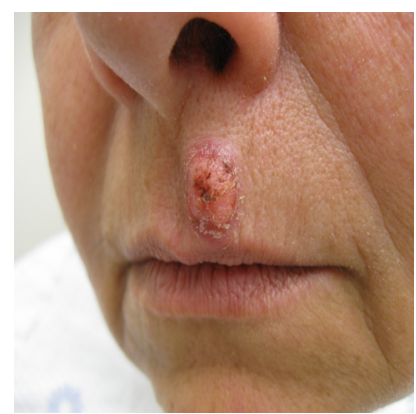

Figure 2. A central cystic area is filled with keratinaceous debris. Proliferation of keratinocytes is noted and a dense infiltrate of lymphocytes surrounds the central keratinocytic proliferation. (Hematoxylin and eosin stained sections. Original magnification 100x).

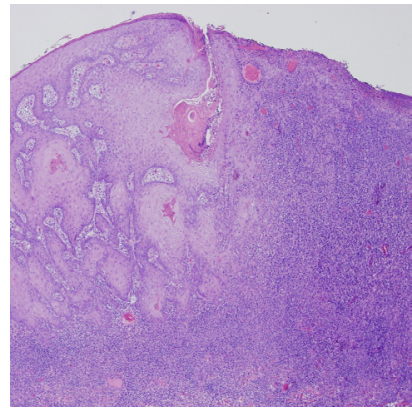

Figure 3. A CD30 stain decorates the large and atypical lymphocytes adjacent to the squamous proliferation with a membranous pattern. (Original magnification 400x).

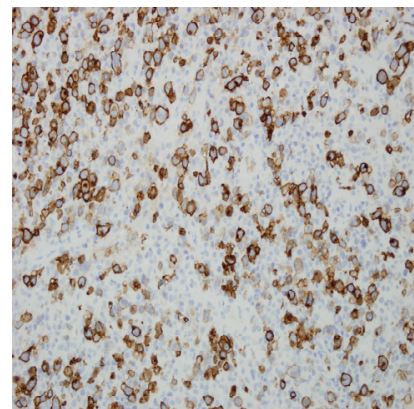

not identified. Clinical correlation is often required for definitive diagnosis, as the histologic findings may exactly mimic squamous cell carcinoma in some. Spontaneous resolution of the epidermal changes often occurs in cases where the underlying lymphoproliferative disease is brought under control. Simple excision is typically curative.

Although differentiation can be difficult on a histologic basis, the clinical course provides useful information for differentiation. $\mathrm{PEH}$ in the setting of $\mathrm{CD} 30+$ disease often regresses spontaneously and the epithelial component fails to reveal high grade features or features such as perineural invasion. When the histological findings and clinical course provide a confusing picture, molecular analysis may prove helpful. DNA microarrays have demonstrated important differences between squamous cell carcinoma and pseudoepitheliomatous hyperplasia. A TaqMan PCR assay based on KRT9 and C15orf48 can help differentiate PEH from squamous cell carcinoma in the majority of cases [11]. Clinicians and pathologists should be aware of the striking similarity of PEH with SCC in such cases, to allow for accurate diagnosis and to avoid unnecessarily aggressive surgical management.

\section{References}

[1]. Guitart J, Gordon K. Keratoacanthomas and lymphomatoidpapulosis. Am J Dermatopathol.1998 Aug; 20(4):430-433. PubMed PMID: 9700388.

[2]. Price A, Miller JH, Junkins-Hopkins JM. Pseudocarcinomatous hyperplasia in anaplastic large cell lymphoma, a mimicker of poorly differentiated squamous cell carcinoma: report of a case and review of the literature. J Cutan Pathol. 2015 Nov;42(11):863-869. PubMed PMID: 26040921.

[3]. Guitart J, Martinez-Escala ME, Deonizio JM, Gerami P, Kadin ME. $\mathrm{CD} 30+$ cutaneous lymphoproliferative disorders with pseudocarcinomatous hyperplasia are associated with a T-helper- 17 cytokine profile and infiltrating granulocytes. J Am Acad Dermatol. 2015 Mar;72(3):508-15. PubMed PMID: 25582534.

[4]. Cespedes YP, Rockley PF, Flores F, Ruiz P, Kaiser MR, et al. Is there is a special relationship between CD30 positive lymphoproliferative disorders and epidermal proliferation? J Cutan Pathol. 2000 Jul;27(6):271-275.

[5]. Bax MJ, Helm MA, Conroy DR, Grassi M, Bogner P. Pseudoepitheliomatous Hyperplasia Associated with CD30+ lymphoproliferative disease: a potential mimic of squamous cell carcinoma. Presented at the 51st ASDP meeting in Chicago, IL; 2014 Nov 9.

[6]. Kadin ME, Hughey LC, Wood GS. Large-cell transformation of mycosis fungoides-differential diagnosis with implications for clinical management: a consensus statement of the US Cutaneous Lymphoma Consortium. J Am Acad Dermatol. 2014 Feb;70(2):374-376. PubMed PMID: 24438952.

[7]. Wu H, Telang GH, Lessin SR, Vonderheid EC. Mycosis fungoides with CD30-positive cells in the epidermis. Am J Dermpath. 2000 Jun;22(3):2126. PubMed PMID: 10871063. 
[8]. Scarisbrick JJ, Calonje E, Orchard G, Child FJ, Russell-Jones R. Pseudocarcinomatous change in lymphomatoidpapulosis and primary cutaneous CD30+ lymphoma: a clinicopathologic and immunohistochemical study of 6 patients. J Am Acad Dermatol. 2001 Feb;44(2):239-247. PubMed PMID: 11174381

[9]. Ling Y-H, Zhu C-M, Wen S-H, Luo R-Z, Li P, Cao Y, et al. Pseudoepitheliomatous hyperplasia mimicking invasive squamous cell carcinoma in extranodal natural killer/T-cell lymphoma: a report of 34 cases. Histopathology. 2015 Sep;67(3):404-409. PubMed PMID: 25619876.
[10]. Chakrabarti S, Chakrabarti PR, Agrawal D, Somanath S. Pseudoepitheliomatous Hyperplasia: A Clinical Entity Mistaken for Squamous Cell Carcinoma. J Cutan Aesthet Surg. 2014 Dec;7(4):232-234. PubMed PMCID: PMC4338470.

[11]. Su A, Ra S, Li X, Zhou J, Binder SW. Differentiating cutaneous squamous cell carcinoma and pseudoepitheliomatous hyperplasia by multiplex qRTPCR. Mod Pathol. 2013 Nov;26(11):1433-7. 